DOI: $10.17976 / \mathrm{jpps} / 2018.02 .05$

\title{
ЭТНОСОЦИАЛЬНАЯ СИТУАЦИЯ \\ В АРКТИЧЕСКИХ РЕГИОНАХ РОССИИ \\ И ГОСУДАРСТВЕННАЯ НАЦИОНАЛЬНАЯ ПОЛИТИКА
}

\author{
К.С. Зайков, А.М. Максимов, А.М. Тамицкий, Т.И. Трошина
}

ЗАЙКОВ Константин Сергеевич, кандидат исторических наук, директор Арктического центра стратегических исследований Северного (Арктического) федерального университета им. М.В. Ломоносова, Архангельск. Для связи с автором: k.zaikov@narfu.ru; МАКСИМОВ Антон Михайлович, кандидат политических наук, доцент кафедры философии и социологии Северного (Арктического) федерального университета им. М.В. Ломоносова, Архангельск. Для связи с автором: a.m.maksimov@narfu.ru; ТАМИЦКИЙ Александр Михайлович, кандидат политических наук, доцент кафедры регионоведения, международных отношений и политологии Северного (Арктического) федерального университета им. М.В. Ломоносова, Архангельск. Для связи с автором: a.tamitskij@narfu.ru; ТРОШИНА Татьяна Игоревна, доктор исторических наук, профессор кафедры социальной работы и социальной безопасности Северного (Арктического) федерального университета им. М.В. Ломоносова, Архангельск. Для связи с автором: t.troshina@narfu.ru

Зайков К.С., Максимов А.М., Тамицкий А.М., Трошина Т.И. Этносоциальная ситуация в арктических регионах России и государственная национальная политика. - Полис. Политические исследования. 2018. № 2. С. 57-67. https://doi.org/10.17976/jpps/2018.02.05

Исследование выполнено при грантовой поддержке Российского научного фонда (проект № 15-18-00104 “Российская Арктика: от концептуализации к эффективной модели государственной этнонациональной политики в условиях стабильного развития регионов”).

Статья поступила в редакцию: 24.04.2017. Принята к печати: 16.08.2017

Аннотация. В статье представлены результаты социологического исследования состояния межнациональных отношений в Архангельской области и Ненецком автономном округе, входящих в состав Арктической зоны РФ. В ходе проведенного массового опроса выявлена статистически значимая группа респондентов, негативно оценивающая состояние межнациональных отношений, а также распространенность среди населения устойчивого негативного отношения к отдельным этническим меньшинствам. Массовый опрос дополнен материалами серии экспертных интервью и статистическими данными. Сопоставление и интерпретация эмпирических данных позволили сделать вывод об отсутствии в двух исследуемых субъектах федерации социально-экономических, демографических и культурных предпосылок к росту межэтнической напряженности, но также и о распространенности среди части населения негативных оценок в отношении отдельных этнических групп, которые основаны на дискурсивно воспроизводимых этнических гетеростереотипах.

Ключевые слова: межэтнические отношения; этнические меньшинства; национальная государственная политика; конструктивизм в этнологии; этническая идентичность; Арктическая зона Российской Федерации.

\section{Введение}

Россия, будучи многонациональным государством, сталкивается с комплексом проблем, типичных для любой страны со сложным этнокультурным составом населения и непростой историей межэтнических взаимоотношений. Акцентирование внимания общественности на этнокультурных различиях способствует популярности среди населения идей этнонационализма, что осложняет реализацию проекта формирования российской гражданской 
нации. Это, в свою очередь, создает основы для перезапуска политическим руководством страны государственной этнонациональной политики [Попков, Костюк 2015]. В частности, впервые после 1996 г. был разработан и утвержден новый программный документ в этой сфере ${ }^{1}$.

Политики, чиновники, а отчасти и экспертное сообщество нередко осмысливают и описывают этносоциальные процессы в категориях дискурса, подразумевающего реификацию множества абстрактных понятий, что само по себе способно провоцировать возникновение этнополитических проблем². Именно поэтому столь необходимо научное сопровождение государственной национальной политики.

В России за последние годы проведено значительное количество эмпирических исследований, посвященных межэтнической ситуации как в полиэтничных [Гусаева 2006; Мазурина 2008; Фролова 2006], так и в моноэтничных регионах [Анциферова 2015; Брянцев 2008; Дружинин 2015]. Вместе с тем расширение географии исследований и увеличение эмпирических данных не сопровождаются радикальным отказом от эссенциалистских (примордиалистских) представлений о природе этничности. Хотя в обширной литературе, посвященной проблеме обновления теоретического арсенала этнологии, встречается немало работ, в которых фиксируется рецепция российским академическим сообществом конструктивистской и даже постмодернистской критики [Винер 2005; Здравомыслов, Цуциев 2001; Рыбаков 2011], методологическая эклектичность остается чертой, присущей данной научной дисциплине [Арутюнян и др. 2016: 79-80].

Для нас представляется очевидной непродуктивность восприятия ключевых этнических феноменов (групп, идентичностей, культурных различий) как укорененных в социальном пространстве, отграниченных друг от друга, стабильных и самодостаточных элементов, придающих социальной структуре дискретность и “жесткость”. Равно сомнительным мы считаем и тезис об этничности как о базовой характеристике индивидов, изначально им присущей в силу объективных внешних обстоятельств (происхождение, родной язык и пр.), поскольку он не стыкуется, например, с фактами "появления" и "исчезновения" этнических групп в зависимости от изменений в юридически утвержденной номенклатуре народов, используемой при проведении переписей населения [Соколовский 2005: 151-155; Тишков 2003: 179-208]. В связи с этим в данной работе мы отдаем предпочтение теоретическим наработкам конструктивистского подхода [Андерсон 2001; Ethnic Groups and Boundaries... 1969; Brubaker 2004; Соколовский 2012; Тишков 2016]. Конструктивистская теория будет использована далее в качестве концептуальной рамки для интерпретации эмпирических данных в части дискурсивного воспроизводства этнических гетеростереотипов, связанных с ними представлений об угрозах со стороны иноэтничных элементов в социальном пространстве региона, и, как следствие, барьерах на пути решения задач национальной политики по консолидации российской нации.

\footnotetext{
1 О Стратегии государственной национальной политики Российской Федерации на период до 2025 года: Указ Президента РФ от 19.12.2012 № 1666. - Собрание законодательства РФ. 24.12.2012. № 52. Ст. 7477.

2 Об этой проблеме применительно к нации см. [Балибар, Валлерстайн 2004: 95-98], к классу - см. [Бурдье 2007: 17-20], к этносу - см. [Brubaker 2004: 7-10].
} 


\section{МЕЖНАЦИОНАЛЬНЫЕ ОТНОШЕНИЯ В АРХАНГЕЛЬСКОЙ ОБЛАСТИ И НЕНЕЦКОМ АВТОНОМНОМ ОКРУГЕ}

В июле-ноябре 2015 г. авторами проведено эмпирическое исследование “Этнокультурный ландшафт Российской Арктики: ценности, традиции, отношения", в ходе которого осуществлен массовый выборочный опрос жителей территорий Архангельской области и Ненецкого автономного округа (далее HАО), входящих в состав Арктической зоны РФ. Тип выборки - квотная (по полу, возрасту и району проживания пропорционально долям в генеральной совокупности). Объем выборки составил 700 чел., или 0,001\% от генеральной совокупности. Статистическая погрешность не превышала 3,7\%. В анкету были включены закрытые, полузакрытые и открытые вопросы (общее количество - 39). Большинство респондентов (93\%) в графе национальность указали "русский", что соответствует доле русских в составе населения региона $(95,6 \%)^{3}$. Русский язык в качестве родного указали $97 \%$ опрошенных.

Одна из задач исследования заключалась в определении установок населения по отношению к людям различных национальностей, что представляет научный и практический интерес в контексте исследования проблем толерантности и профилактики межэтнических конфликтов. Согласно данным общероссийского мониторинга межэтнической напряженности, Архангельская область относится к благополучным регионам ${ }^{4}$. В ходе проведенного опроса данное экспертное заключение получило подтверждение: на вопрос "ошущается ли сейчас в городе/районе Вашего нынешнего проживания межээтническая напряженность?” 22\% респондентов дали отрицательный ответ, еще $45 \%$ скорее склоняются к отрицательному ответу, $9 \%$ респондентов склоняются к признанию наличия напряженности в отношениях между представителями разных национальностей. При этом в областном центре доля таких ответов выше и составляет 12\%. Схожим образом оценивается респондентами риск возникновения насильственных межэтнических конфликтов. $45 \%$ респондентов сомневаются в возможности столкновения на национальной почве в регионе проживания; 29\% опрошенных однозначно утверждают, что таковых быть не может. В то же время 6\% опрошенных допускают такую вероятность, а 2\% респондентов дали утвердительный ответ на этот вопрос.

Тем респондентам, кто положительно ответил на вопрос о межэтнической напряженности в регионе, было предложено назвать ее возможные причины. Наиболее часто приводились такие ответы, как несовместимость норм поведения, рост численности представителей этнических меньшинств, агрессивность поведения представителей отдельных народов и конкуренция за рабочие места. Полные данные по ответам респондентов приведены в табл. 1.

Респондентам также был задан вопрос, позволяющий дифференцировать их отношение (положительное, нейтральное или негативное) к выходцам из северокавказских республик и республик бывшего СССР. Последние были разделены на три группы: государства к западу от РФ (за исключением стран Балтии), закавказские и среднеазиатские страны. Как видно из табл. 2, где приводится детальное распределение ответов, доля отрицательных оценок стабильно выше по отношению ко всем категориям лиц, кроме выходцев из Украины, Беларуси и Молдовы.

\footnotetext{
3 Всероссийская перепись населения 2002 года. Том 4. Национальный состав и владение языками, гражданство. - Федеральная службба государственной статистики. Доступ: http://www.perepis2002.ru/ index.html? id=17 (проверено 10.01.2018).

4 Гроздья гнева. Рейтинг межэтнической напряженности в регионах России. Весна - осень 2014 года. Доступ: http://club-rf.ru/thegrapesofwrath/02/ (проверено 10.01.2018).
} 


\section{Мнение респондентов о возможных причинах межэтнической напряженности} в Архангельской области и НАО

(среди тех, кто положительно ответил на вопрос о межэтнической напряженности в регионе; допускался выбор нескольких вариантов ответа, $\mathrm{N}=63$ чел.)

Respondents' Opinions on Possible Causes of the Ethnic Tensions in the Arkhangelsk Oblast and Nenets Autonomous Okrug

(among those who positively answered the question on ethnic tensions in the region, more than one answer possible, $N=63$ )

\begin{tabular}{|l|c|}
\hline \multicolumn{1}{|c|}{ Вариант ответа } & Частота \\
\hline Несовместимые нормы и правила поведения & 30 \\
\hline Быстрый рост численности этнических меньшинств & 25 \\
\hline Агрессивность в межгрупповых отношениях, конфликтное поведение & 25 \\
\hline Конкуренция за рабочие места & 23 \\
\hline Вызывающие формы повседневного бытового поведения & 19 \\
\hline Усиление криминогенной обстановки в среде этнических меньшинств & 18 \\
\hline Доминирование этнических меньшинств в определенных сферах занятости & 13 \\
\hline Показное благосостояние представителей этнических меньшинств & 12 \\
\hline Требование особых прав и льгот для этнических меньшинств & 12 \\
\hline
\end{tabular}

таблица 2 (Table 2)

Отношение респондентов к выходщам из постсоветских стран и некоторых автономных республик РФ

(абсолютные значения и \%; $\mathrm{N}=700$ )

Respondents' Attitudes to People Originally from the Republics of the Former USSR and Some Autonomous Republics of the Russian Federation

(absolute values and per cent, $N=700$ )

\begin{tabular}{|l|c|c|c|c|}
\hline & $\begin{array}{c}\text { Из Украины, } \\
\text { Беларуси, } \\
\text { Молдовы }\end{array}$ & $\begin{array}{c}\text { Из стран } \\
\text { Закавказья }\end{array}$ & $\begin{array}{c}\text { Из стран } \\
\text { Средней } \\
\text { Азии }\end{array}$ & $\begin{array}{c}\text { Из республик } \\
\text { Северного } \\
\text { Кавказа }\end{array}$ \\
\hline Положительное & $197(28,1 \%)$ & $96(13,7 \%)$ & $76(10,9 \%)$ & $82(11,7 \%)$ \\
\hline Нейтральное & $419(59,9 \%)$ & $387(55,3 \%)$ & $390(55,7 \%)$ & $338(48,3 \%)$ \\
\hline Отрицательное & $33(4,7 \%)$ & $126(18 \%)$ & $134(19,1 \%)$ & $170(24,3 \%)$ \\
\hline Затруднились ответить & $51(7,3 \%)$ & $91(13 \%)$ & $100(14,3 \%)$ & $110(15,7 \%)$ \\
\hline
\end{tabular}

При этом ответ на вопрос: “Какие чувства Вы лично испытываете по отношению к приезжим, проживающим в городе/районе Вашего нынешнего проживания?" - позволяет раскрыть отношение респондентов не только к трудовым и иного рода мигрантам, недавно приехавшим в регион из бывших советских республик, но и к тем, кого они идентифицируют как выходцев из этих стран по происхождению - вне зависимости от их нынешнего гражданства и срока проживания в регионе.

Таким образом, в ходе опроса были получены данные, хоть и подтверждающие статус Архангельской области как относительно мирного с точки зрения межэтнических отношений региона, но вместе с тем указывающие 
на риск возникновения межэтнической напряженности. Мы увязываем это со следующими факторами:

1) распространенность ксенофобских настроений среди жителей области по отношению к приезжим из республик Северного Кавказа, а также из государств Средней Азии и Закавказья, что подтверждается приведенными выше данными опроса;

2) наличие в составе населения статистически значимого меньшинства, оценивающего состояние межэтнических отношений как неблагоприятное и описывающего их в терминах напряженности и конфликта;

3) распространенность среди этой части населения представлений об этнических меньшинствах как об источниках угрозы своему социальноэкономическому благополучию и безопасности. Логично предположить, что эти представления обусловливают и негативное отношение к отдельным этническим группам, и общее ощущение межэтнической напряженности.

За ответами на вопрос о возможных причинах межэтнической напряженности легко просматриваются дискурсивно воспроизводимые коллективные представления. Их содержание сводится к следующему:

1) отрицательный прирост населения в “русских” регионах создает условия для “замещающей” иноэтничной иммиграции, что в случае значительной культурной дистанции между “местными” и “приезжими” может служить фактором роста потенциала конфликтного взаимодействия;

2) рост численности иностранной рабочей силы ведет к ужесточению конкуренции за рабочие места между местным населением и трудовыми мигрантами; в сочетании с этническим предпринимательством данное обстоятельство становится причиной социальных конфликтов, маркируемых как межэтнические.

Далее мы покажем, что имеется существенное расхождение между этими представлениями и статистическими данными, отражающими состояние соответствующих социальных процессов.

\section{ДЕМОГРАФИЧЕСКАЯ И ЭТНОКУЛЬТУРНАЯ СИТУАЦИЯ В АРХАНГЕЛЬСКОЙ ОБЛАСТИ И НЕНЕЦКОМ АВТОНОМНОМ ОКРУГЕ}

В настоящее время в Архангельской области наблюдается неблагоприятная демографическая ситуация: за период с 1990 г. численность населения сократилась на 24,6\%5. В этих условиях теоретически возможно замещение выбывающих из состава населения местных жителей мигрантами, в том числе из других государств или же “нерусских” субъектов РФ. Именно это обстоятельство вызывает обеспокоенность определенной части местного населения. Однако данные Федеральной миграционной службы и Росстата не подтверждают наличия “замещающей” миграции в смысле заметного увеличения числа иноэтничных мигрантов. Доля последних в сравнении с общей численностью населения региона крайне незначительна: в период 2011-2014 гг. разрешительные документы на работу получало немногим более 3600 чел. в среднем за год, а в 2015 г. - всего 2 0016. Что же касается масштабов

\footnotetext{
${ }^{5}$ Доклад “О миграционной ситуации в Архангельской области, основных результатах деятельности УФМС России по Архангельской области” за 2015 год. Архангельск. 2016.

${ }^{6}$ Там же, с. 24.
} 
нелегальной трудовой миграции, которая нередко становится источником беспокойства общественности, то ее уровень, по оценке УФМС, также незначителен - немногим более 2000 чел. на 2015 г. $^{7}$

В НАО иная ситуация: на протяжении нескольких последних лет наблюдался некоторый рост населения [Синица 2016: 20], связываемый с притоком трудовых мигрантов, задействованных на предприятиях по добыче полезных ископаемых [Соколова 2016: 169]. Вместе с тем коэффициент миграционного прироста в 2016 г. имел отрицательное значение. Однако в период 2014-2016 гг. рождаемость стабильно превышала смертность примерно в два раза ${ }^{8}$. Из этого следует, что и НАО не может рассматриваться в качестве региона с потенциалом "замещающей” миграции.

Необходимо указать и на то обстоятельство, что снижение численности русского населения Архангельской области и НАО сопровождается аналогичной динамикой среди этнических меньшинств названных регионов (см. табл. 3).

Таблица 3 (Table 3)

\section{Динамика численности представителей различных этнических групII на территории Архангельской области и НАО \\ Dynamics of the Number of Representatives of Various Ethnic Groups in the Arkhangelsk Oblast and Nenets Autonomous Okrug}

\begin{tabular}{|l|c|c|c|}
\hline $\begin{array}{c}\text { Национальная } \\
\text { принадлежность }\end{array}$ & $\begin{array}{c}\text { Перепись 2002 г. } \\
\text { (тыс. чел.) }\end{array}$ & $\begin{array}{c}\text { Перепись 2010 г. } \\
\text { (тыс. чел.) }\end{array}$ & $\begin{array}{c}\text { Изменение, } \\
\text { \% }\end{array}$ \\
\hline Русские & 1258,9 & 1148,8 & $-8,7$ \\
\hline Украинцы & 27,8 & 16,9 & $-39,2$ \\
\hline Белорусы & 10,4 & 5,8 & $-44,2$ \\
\hline Татары & 3,3 & 2,3 & $-30,3$ \\
\hline Азербайджанцы & 3,0 & 2,6 & $-13,3$ \\
\hline Армяне & 1,1 & 1,0 & $-9,1$ \\
\hline Ненцы & 8,3 & 8,0 & $-3,6$ \\
\hline Коми & 5,7 & 4,6 & $-19,3$ \\
\hline Чуваши & 1,9 & 1,4 & $-26,3$ \\
\hline
\end{tabular}

Источники: Всероссийская перепись населения 2002 года. Том 4. Национальный состав и владение языками, гражданство. - Федеральная служба государственной статистики; Всероссийская перепись населения 2010 года. Том 4. Национальный состав и владение языками, гражданство. Федеральная служба государственной статистики.

Сокращение трудовой иммиграции в 2015 г. более чем на треть по сравнению с 2014 г. говорит само за себя. Разумеется, уменьшение численности иностранной рабочей силы обусловлено рецессией в региональной экономике, что предполагает рост напряженности на рынке труда, но следует заметить, что иноэтничные мигранты в большинстве своем привлекаются на низкооплачиваемые и физически тяжелые работы, которые малопривлекательны для местных жителей и не становятся предметом конкурентной борьбы с их стороны.

\footnotetext{
${ }^{7}$ Там же, с. 29.

${ }^{8}$ Важнейшие показатели социально-экономического развития Ненецкого автономного округа. Департамент финансов и экономики Ненецкого автономного округа. Доступ: http://dfei.adm-nao.ru/ statisticheskaya-informaciya/statisticheskie-dannye-i-pokazateli/ (проверено 01.02.2018).
} 
Сложнее обстоит дело с влиянием этнокультурных различий на межэтнические отношения и их восприятие в обыденном сознании. На первый взгляд, различие социокультурных норм разных народов не должно вызывать сомнений, поскольку именно оно лежит в основе этнической самоидентификации индивидов. Вместе с тем убежденность в несовместимости поведенческих норм и культурных традиций русских и представителей некоторых этнических меньшинств имплицитно содержит в себе одну фундаментальную предпосылку, а именно, что эти нормы и традиции широко распространены в соответствующей этнической среде и играют важную роль в повседневных социальных практиках.

О роли традиционных, в том числе религиозных, норм, обрядов и обычаев в среде этнических меньшинств Архангельской области дают представление результаты экспертного опроса, проведенного одним из авторов в июле-сентябре 2015 г. методом полуструктурированного глубокого интервью. Всего было опрошено 15 экспертов, отобранных по принципу целенаправленной интенсивной выборки, включающей наиболее информативно значимые субъекты. В нее вошли:

1) руководители землячеств и национально-культурных автономий, представляющие наиболее крупные и организованные этнические менышинства региона - семь интервью;

2) руководители этноконфессиональных региональных организаций - по одному от мусульманской, иудейской и лютеранской;

3) сотрудники регионального ведомства, уполномоченного в сфере государственной национальной политики, - два интервью;

4) представители правозащитных и просветительских НКО, занимающиеся проблемами межкультурной коммуникации, - три интервью [Максимов 2016].

Эксперты отметили трудности удовлетворения ряда культурных потребностей, необходимых для поддержания нерусским населением своей конфессиональной идентичности. Прежде всего это касается сложностей при организации отправления религиозных обрядов среди неправославных. В основном эксперты говорят о нехватке в регионе культовых сооружений для мусульман, иудеев, последователей некоторых христианских конфессий.

Интересно отметить, что почти все эксперты указывают на снижение интереса у большинства представителей этнических меньшинств (за исключением старшей возрастной категории) к сохранению родного языка и участию в публичных этнокультурных мероприятиях. Самое болышее - этническая культура воспроизводится в узком кругу семьи и близких друзей в форме некоторых национальных праздников и религиозных ритуалов (намаз), специфических бытовых привычек (например, гастрономических) и наличия минимальных знаний из области фольклора.

Эксперты из числа руководителей национально-культурных автономий и землячеств свидетельствуют, что их земляки используют русский как язык повседневного общения не только по месту работы, в государственных учреждениях и т.д., где им приходится коммуницировать преимущественно с русскими, но нередко и в семейном кругу. Многие украинцы, белорусы, татары, чуваши, евреи, российские немцы говорят только на русском языке - для них он единственный родной в силу слабого знания или полного незнания языка своей национальности.

Можно сделать вывод о том, что давно проживающие на исследуемых территориях лица, идентифицируюшие себя с тем или иным этническим меньшинством, подверглись заметной аккультурации и, следовательно, этнокультурные барьеры для успешной коммуникации между ними и русским большинством практически отсутствуют. Что же касается мигрантов из других стран, пребывающих 
в Архангельскую область и НАО, то их крайняя малочисленность и специфика организации быта и трудовой деятельности сводят их повседневную коммуникацию с местным населением к минимуму. Кроме того, среди мигрантов значительна доля украинцев, культурно близких к русским, которые по этой причине не испытывают серьезных трудностей во взаимодействии с местным населением.

\section{ЗАКЛЮЧЕНИЕ}

Таким образом, результаты проведенного анализа не позволяют утверждать, что существуют социально-экономические, демографические или культурные предпосылки для реализации тех факторов межэтнической напряженности, на которые указывает часть респондентов. Тем не менее эти респонденты артикулируют мнение об отдельных этнических меньшинствах как о чужеродном элементе - источнике конфликтов на почве культурных различий и экономической конкуренции. Логично предположить, что в данном случае такого рода представления базируются на негативных этнических гетеростереотипах, воспроизводимых в практиках СМИ и части политического истеблишмента в рамках дискурса этнонационализма. Еще П. Бурдье показал, как агенты поля политики, обладающие существенным объемом символического капитала, присваивают себе монопольное право дискурсивного производства картины социального мира, включая легитимное право категоризации, классификации, интерпретации и оценки различных социальных феноменов. Эффектом публичной репрезентации сконструированной таким способом картины мира становится формирование комплекса диспозиций, интерсубъективно разделяемых широкими массами [Bourdieu 1992: 107-136]. Этот подход в полной мере применим к формированию и распространению коллективных представлений о природе этничности, этнических общностях и межэтнических взаимоотношениях. Важно подчеркнуть, что в нашем случае речь идет не столько о прямом воздействии националистической пропаганды как таковой. После запрещения ультранационалистических организаций ДПНИ, “Славянский союз”, “Русские” и радикальных исламистских группировок националистическая пропаганда в ее наиболее одиозных формах ушла на периферию пространства публичной коммуникации. Однако дискурс этнонационализма может воспроизводиться и в иных формах, таких как объективация этничности, классификация людей по этническому признаку, маркирование определенных событий и аспектов человеческого поведения как этнических по своей природе [Brubaker 2004: 16-18].

В связи с этим вызывает вопросы проникновение элементов дискурса этнонационализма в программные документы органов государственной власти. Не вдаваясь в детальный анализ, укажем в качестве выразительного примера на формулировки и смысловую нагрузку задач в Стратегии государственной национальной политики. В частности, целевая установка на поддержание разнообразия этнокультурного ландшафта имплицитно содержит примордиалистскую интерпретацию феномена этничности как имманентного свойства объективно существующих групп населения. Следуя этой логике, не менее важная задача укрепления единства российской нации может быть решена посредством своеобразного “плавильного котла”, в котором вышеупомянутое этнокультурное разнообразие неизбежно нивелируется. Согласно же нашей точке зрения, этничность следует рассматривать как ситуативный продукт “политики идентичности”, в которую вовлечены представители академического сообщества, государственной бюрократии и непосредственно сами граждане 
[Соколовский 2012: 78-80]. При такой трактовке снимается проблема совместимости двух названных задач национальной политики, поскольку национальная идентичность (в смысле отнесения себя к российской гражданской нации) не устраняет идентичность этническую, а дополняет, надстраивается над ней. В зависимости от контекста конкретной ситуации индивиды могут маневрировать между различными регистрами собственной идентичности - позиционировать себя в качестве россиян в рамках многообразных публичных институтов и в качестве представителей этнической группы, будучи вовлеченными в многообразные практики социальных взаимодействий. В первом случае граждане будут демонстрировать приверженность общероссийским гражданским ценностям, а во втором - специфическим этнокультурным традициям.

В дальнейшей перспективе академическому сообществу в единстве с государственной властью, в том числе регионального уровня, необходимо рассмотреть возможность применения концептуальной альтернативы принципу дифференциации населения на основе набора культурно отличительных признаков. В этом контексте допускается возможность так называемого дрейфа, или множественности идентичности, поскольку самоидентификация с тем или иным “воображаемым" сообществом имеет ситуативный и контекстуальный характер. В этом видится перспектива преодоления дихотомии национального и этнокультурного, полагаемой несовместимости гражданского единства в границах национального государства и протекционистских установок на сохранение и воспроизводство “своих” особых культурно-бытовых традиций.

Андерсон Б. 2001. Воображаемые сообщества. Размышления об истоках и распространении национализма. М.: Канон-Пресс-Ц, Кучково поле. 288 с.

Анциферова Н.Г. 2015. Межэтнические и межкультурные отношения в моноэтничном приграничном регионе: состояние и тенденции развития (на примере Курской области). - Научный руководитель. № 2(9). С. 10-15.

Арутюнян Ю.В., Губогло М.Н., Дробижева Л.М., Комарова Г.А. 2016. Этносоциология: вчера, сегодня, завтра. - Феномен междисциплинарности в отечественной этнологии. М.: Институт этнологии и антропологии им. Н.Н. МиклухоМаклая РАН. С. 78-99.

Балибар Э., Валлерстайн И. 2004. Раса, нация, класс. Двусмысленные идентичности. М.: Логос. 288 с.

Брянцев И.И. 2008. Актуальные проблемы этнокультурной политики в субъекте РФ: социологическое сопровождение и властные решения. - Вестник Поволжского института управления. № 4. С. 53-62.

Бурдье П. 2007. Социология социального пространства. М.: Институт экспериментальной социологии; СПб.: Алетейя. 288 с.

Винер Б.Е. 2005. Постмодернистский конструктивизм в российской этнологии. Журнал социологии и социальной антропологии. Т. VIII. № 3. С. 114-130.

Гусаева К.Г. 2006. Межнациональные и межконфессиональные отношения в Дагестане: от конфликтности к стабильности. Махачкала: Наука плюс. 296 с.

Дружинин А.Г. 2015. Этнодемографические трансформации в центро-периферийной структуре Ростовской области (постсоветские тренды). - Региональные исследования. № 3(49). С. 78-85.

Здравомыслов А.Г., Цуциев А.А. 2001. Этничность в постсоветском пространстве: соперничество теоретических парадигм. - Вестник Института цивилизащии. № 4. С. 125-154.

Мазурина Н.Г. 2008. Межнациональные отношения в условиях полиэтнического мегаполиса (на материалах г. Москвы). Дис. ... канд. социолог. наук: 22.00.04. М.

Максимов А.М. 2016. Государственная национальная политика в моноэтническом регионе: модель взаимодействия с этническими меньшинствами (на примере Архангельской области). - Теории и проблемы политических исследований. № 1. С. 153-171. 
Попков Ю.В., Костюк В.Г. 2015. Проблемное поле национальной политики в современной России. - Вестник Новосибирского государственного университета. Серия: Философия. Т. 13. № 3. С. 71-80.

Рыбаков С.Е. 2011. О методологии исследования этнических феноменов. Личность. Культура. Общество. Т. ХІІІ. № 3 (65-66). С. 153-165.

Синица А.Л. 2016. Демографическое развитие регионов Арктической зоны России в 2010-2014 гг. - Арктика: экология и экономика. № 1(21). С. 18-27. Доступ: http://eng. arctica-ac.ru/docs/1(21)2016/018_027_ARCTICA_1_2016.pdf (проверено 10.01.2018).

Соколова Ф.Х. 2016. Миграционные процессы в Российской Арктике. - Арктика и Север. № 25. С. 158-172.

Соколовский С.В. 2005. Институты и практики производства и воспроизводства этничности. - Этнометодология: проблемы, подходы, концепции. Вып. 11. С. 144-167.

Соколовский С.В. 2012. Современный этногенез или политика идентичности? Этнографическое обозрение. № 2. С. 77-83.

Тишков В.А. 2003. Реквием по этносу: Исследования по социально-культурной антропологии. М.: Наука. 544 с.

Тишков В.А. 2016. От этноса к этничности и после. - Этнографическое обозрение. № 5. C. 5-22.

Фролова Е.В. 2006. Современные этнические процессы в среде групп этнических меньшинств: на примере городов Казань и Набережнные Челны Республики Татарстан. Автореф. дис. ... канд. ист. наук: 07.00.07. Казань. 22 с.

Bourdieu P. 1992. Language and Symbolic Power. Cambridge, UK: Polity Press. IX, 302 p.

Brubaker R. 2004. Ethnicity without Groups. Cambridge, Mass.: Harvard University Press. 283 p.

Ethnic Groups and Boundaries. The Social Organization of Culture Difference. 1969. Ed. by F. Barth. Oslo: Universitetsforlaget AS. 153 p.

\title{
ETHNOSOCIAL SITUATION IN ARCTIC REGIONS OF RUSSIA AND THE STATE NATIONAL POLICY
}

\author{
K.S. Zaykov ${ }^{1}$, A.M. Maksimov ${ }^{1}$, A.M. Tamitskiy ${ }^{1}$, T.I. Troshina ${ }^{1}$ \\ ${ }^{1}$ Northern (Arctic) Federal University named after M.V. Lomonosov. Arkhangelsk, Russia
}

ZAYKOV Konstantin Sergeevich, Cand. Sci. (Hist.), Head of the Arctic Centre for Strategic Studies, Northern (Arctic) Federal University named after M.V. Lomonosov. Email: k.zaikov@narfu.ru; MAKSIMOVAnton Mikhailovich, Dr. Sci. (Pol. Sci.), Associate Professor, Northern (Arctic) Federal University named after M.V. Lomonosov. Email: a.m.maksimov@narfu.ru; TAMITSKY Aleksandr Mikhailovich, Dr. Sci. (Pol. Sci.), Associate Professor, Northern (Arctic) Federal University named after M.V. Lomonosov. Email: a.tamitskij@narfu.ru; TROSHINA Tat'yana Igorevna, Dr. Sci. (Hist.), Professor, Northern (Arctic) Federal University named after M.V. Lomonosov. Email: t.troshina@narfu.ru

Zaykov K.S., Maksimov A.M, Tamitskiy A.M., Troshina T.I. Ethnosocial Situation in Arctic Regions of Russia and the State National Policy. - Polis. Political Studies. 2018. No. 2. P. 57-67. (In Russ.) https://doi.org/10.17976/jpps/2018.02.05

Acknowledgements. The research was supported by the Russian Science Foundation via grant no. 15-18-00104 "Russian Arctic: from conceptualization towards an effective model of the state ethnic and national policy in the context of sustainable development of the regions".

Received: 24.04.2017. Accepted: 16.08 .2017

\begin{abstract}
The article presents the results of the sociological studies of the interethnic relations in the Arkhangelsk region and the Nenets Autonomous District, that are a part of the Arctic zone of the Russian Federation. We held an opinion poll and identified a statistically significant group of respondents that negatively evaluated the state of international relations, as well as the prevalence of a stable negative attitude towards the certain ethnic minorities in the population. The mass survey was supplemented by the materials of the series of expert interviews and statistical data. Comparison and interpretation of empirical values have led to the conclusion about the absence of socio-economic, demographic and cultural preconditions for the growth of ethnic tensions in the study area and about the negative assessments among the part of the population in respect of certain ethnic groups that have been based on the discursive reproduced ethnic hetero-stereotypes. The academic community should promote a rethinking of the idea of ethnic and cultural
\end{abstract}


diversity among the political establishment and the related mass media by offering a conceptual alternative to the idea of the rigid differentiation of the population on the basis of the culturally distinctive features, when every citizen should clearly and permanently identify their ethnicity.

Keywords: inter-ethnic relations; ethnic minorities; national policy; constructivism in ethnology; discursive practices; ethnic identity; Arctic zone of the Russian Federation

\section{References}

Anderson B. Imagined Communities Reflections on the Origin and Spread of Nationalism. (Russ. ed.: Anderson B. Voobrazhaemye soobshestva. Razmyshlenija ob istokakh i rasprostranenii natsionalizma. Moscow: Kanon-Press-TS, Kuchkovo pole. 2001. 288 p.)

Antsiferova N.G. Interethnic and Intercultural Relations in a Mono-Ethnic Cross-Border Region: State and Development Trends (the Case of the Kursk Region). - Nauchnyi rukovoditel'. 2015. No. 2(9). P. 10-15. (In Russ.)

Artyunjan Yu.V., Gubolgo M.N., Drobizheva L.M., Komarova G.A. Etnosotsiologija: vchera, segodnja, zavtra [Sociology: Yesterday, Today, Tomorrow]. - Fenomen mezhdistsiplinarnosti v otechestvennoj etnologii [The Phenomenon of Interdisciplinarity in National Ethnology]. Moscow: Institut etnologii i antropologii im. Miklykho-Maklaja RAN. 2016. P. 79-99. (In Russ.)

Balibar E., Wallerstein I. Race, nation, classe. Les identites ambigues. (Russ. ed.: Balibar E., Wallerstein I. Rasa, nacija, klass. Dvusmyslennye identichnosti. Moscow: Logos. 288 p.)

Bourdieu P. Language and Symbolic Power. Cambridge, UK: PolityPress. 1992. IX, 302 p.

Bourdieu P. Sociologija social'nogo prostranstva [Sociology of Social Space]. Moscow: Institut jeksperimental'noj sociologii; St. Petersburg: Aletejja. 2007. 288 p. (In Russ.)

Brubaker R. Ethnicity without Groups. Cambridge, Mass.: Harvard University Press. 2004. 283 p.

Bryantsev I.I. Urgent Issues of Ethno-Cultural Policy in Subjects of the Russian Federation: Sociological Assistance and Authoritative Decisions. - The Bulletin of the Volga Region Institute of Administration. 2008. No. 4: 53-62. (In Russ.)

Drobizheva L.M. Ethnicity in the Contemporary Society: New Approaches, Old Myths, Social Practices. - Vestnik Instituta sotsiologii. 2010. No. 1. P. 429-442. (In Russ.) URL: http://www.vestnik.isras. ru/files/File/Vestnik 2010 01/drobizheva.pdf (accessed 20.01.2018).

Druzhinin A.G. Etno-Demographic Transformations in the Core-Periphery Structure of the Rostov Region (Post-Soviet Trends). - Regional Research. 2015. No. 3(49). P. 78-85. (In Russ.)

Ethnic Groups and Boundaries. The Social Organization of Culture Difference. Ed. by F. Barth. Oslo: Universitetsforlaget AS. 1969. 153 p.

Frolova E.V. Sovremennye etnicheskie protsesty v srede grupp etnicheskikh men'shinstv: na primere gorodov Kazan' i Naberezhnye Chelny Respubliki Tatarstan. Avtoref. dis. ... kand. ist. nauk [Modern Ethnic Processes in the Ethnic Minority Groups: the Case of the City of Kazan and Naberezhnye Chelny of the Republic of Tatarstan: Cand. Hist. Sci. Diss. Abs.]. Kazan. 2006. (In Russ.)

Gusaeva K.G. Mezhnatsional'nye i mezhkonfessional'nye otnosheniya v Dagestane: ot konfliktnosti $k$ stabil'nosti [Interethnic and Interfaith Relations in Dagestan: from Conflicts to Stability]. Makhachkala: Nauka plyus. 2006. 296 p. (In Russ.)

Maksimov A.M. The State Ethnic Policy in a Mono-Ethnic Region: the Model of Interaction with Ethnic Minorities (as Exemplified by the Arkhangelsk Region). - Theories and Problems of Political Studies. 2016. No. 1. P. 153-171. (In Russ.)

Mazurina N.G. Mezhnatsional'nye otnosheniya v usloviyakh polietnicheskogo megapolisa (na materialakh g. Moskvy). Dis. ... kand. sotsiol. nauk [Interethnic Relations in a Multi-Ethnic Metropolis (the Materials of Moscow): Cand. Soc. Sci. Diss.]. Moscow. 2008. (In Russ.)

Popkov Yu.V., Kostyuk V.G. The Problem Field of Nationalities Policy in Present-Day Russia. - Vestnik of the Novosibirsk State University. Ser.: Philosophy. 2015. Vol. 13. No. 3. P. 71-80. (In Russ.)

Rybakov S.E. On the Methodology of the Study of Ethnic Phenomena. - Lichnost'. Kul'tura. Obshchestvo. 2011. Vol. XIII. No. 3(65-66). P. 153-165. (In Russ.)

Sinitsa A.L. Demograficheskoe razvitie regionov Arkticheskoy zony Rossii v 2010-2014 gg. [Demographic Development of the Russian Arctic Regions in 2010-2014]. The Arctic:ecology and economy. 2016. No. 1(21). P. 18-27. (In Russ.) URL: http://eng.arctica-ac.ru/docs/1(21)2016/018 027 ARCTICA 1 2016.pdf (accessed 10.01.2018).

Sokolova F.H. Migration processes in the Russian Arctic. - Arktika i Sever. $\overline{2016}$. No. 25. P. 158-172. (In Russ.)

Sokolovskiy S.V. Instituty i praktiki proizvodstva i vosproizvodstva etnichnosti [Institutions and Practices of Production and Reproduction of Ethnicity]. - Ethnomethodology: Problems, Approaches, Concepts. 2005. No. 11. P. 144-167. (In Russ.)

Sokolovskij S.V. Modern Ethnogenesis or Identity Politics? - Etnograficheskoe obozrenie. 2012. No. 2. P. 77-83. (In Russ.)

Tishkov V.A. Rekviem po etnosu: Issledovaniya po sotsial'no-kul'turnoy antropologii [Requiem for the Ethnos: the Studies in the Social and Cultural Anthropology]. Moscow: Nauka. 2003. 544 p. (In Russ.)

Tishkov V.A. From Ethnos to Ethnicity and after. - Etnograficheskoe obozrenie. 2016. No. 5. P. 5-22. (In Russ.)

Viner B.E. Post-Modern Constructivism in the Russian Ethnology. - The Journal of Sociology and Social Anthropology. 2005. Vol. VIII. No. 3. P. 114-130. (In Russ.)

Zdravomyslov A.G., Tsutsiev A.A. Ethnicity in the Former Soviet Union: a Rivalry of the Theoretical Paradigms. - Bulletin of the Institute of civilization. 2001. No. 4. P. 125-154. (In Russ.) 